\title{
Framing Islam in News Reporting: A Comparative Content Analysis
}

\author{
Isyaku Hassan ${ }^{1}$, Mohd N. L. Azmi ${ }^{1} \&$ Usman I. Abubakar ${ }^{2}$ \\ ${ }^{1}$ Faculty of Languages and Communication, Sultan Zainal Abidin University, Terengganu, Malaysia \\ ${ }^{2}$ Department of Mass Communication, Bayero University, Kano, Nigeria \\ Correspondence: Isyaku Hassan, Malaysia. Tel: 6-011-337-090-84. E-mail: isyaku87@gmail.com
}

Received: July 31, 2017 Accepted: August 22, $2017 \quad$ Online Published: September 28, 2017

doi:10.5539/ass.v13n10p112 URL: https://doi.org/10.5539/ass.v13n10p112

\begin{abstract}
The emergence of modern communication technology suggests that the society as a whole is now a simple hostage at the hands of the media. However, the time has come to ask whether the people are being managed, manipulated, massaged or brainwashed by the media. Media contents are unjustifiably dominated by expressions that create negative impressions of Islam. As a result, the media accentuate anti-Muslim bias and bigotry. This study aims to comparatively examine how Nigerian and Malaysian newspapers frame Islam-related events in news reporting. Using purposive sampling, Punch and Vanguard were chosen from Nigeria while The Star and New Straits Times were chosen from Malaysia based on their popularity and readership. Relevant news articles that focus upon reports about Islam or Muslims were collected from the selected newspapers using internet-based search from November 2015 until September 2016. The newspapers produced 599 different Islam-related news articles within this period. The study found that out of 599 news articles published in the selected newspapers, 228 portrayed Islam in conflict situation by using conflict frame. For the rest, 60 news articles used consequence frame, 32 used crime frame, 11 used responsibility frame, 19 used morality frame, and 249 portrayed Islam using human interest frame. Nigerian newspapers used more conflict frames in reporting Islam than Malaysian newspapers. Collective efforts of journalists, editors, and corporate ownership of the newspapers should be directed toward suppressing the negative media portrayal of Islam.
\end{abstract}

Keywords: Framing, Islam, language, newspaper, news reporting

\section{Introduction}

The interest in the way media report on religious issues has increased recently. But unethical reporting has raised the question of whether journalists have done more good than harm in covering events and issues that touch upon religion in particular. The essential rules of factual, fair and balanced reporting have been prompted to highlight the rising concern over the media's role in reproducing fear, prejudices, stereotypes and hatred. These worrisome implications of the media representation of religion are significant not only because the media emphasize the difference between 'us' and 'them', but because they propagate fear and tensions instead of promoting peace and tolerance (Rupar, 2012). Journalists with biased mindsets often become propagandists of their personal opinion by using the media as their vehicle.

The traditional role of mass media as defined by the media experts is to inform, educate, entertain, and persuade the people. But today, newspapers are widely used to manipulate information, facts and beliefs (Haque, 2012). Media coverage of specific issues in the Muslim world may be influential in shaping the audiences' attitudes and opinions (Rane, Ewart, \& Martinkus, 2014). The more reliant audiences are on the media, the more potentially vulnerable they are to media influence. Islam is certainly recognized as an expanding religion all over the world. Notwithstanding, many people believe that Islam is commonly interpreted as being retrogressively backward, one-dimensional, inherently separate and "Other" to the West, as well as enemy to modernization and western values. It can be argued that print media continue to play a vital role in the way people perceive religion, and journalists bear a great responsibility in fair representation of religions.

In this digital age of communication, societies depend on the media for information. This overdependence makes the media more powerful in shaping public opinion. Newspapers are considered one of the most powerful sources of information and disseminators of knowledge. Presently, the negative portrayal of Islam might not be unconnected with the unwarranted association of Islam with violence in the media, and this seems to be considered less important in the public debates. The issue of Islam and the media had been debated since the 
aftermath of some events such as the 9/11 attacks in 2001, the Afghanistan war in 2002, the Iraq war in 2003, the Danish cartoon row and the London bombings in 2005, and the recent 2015 attacks in Paris. Therefore, this study aims to comparatively examine the use of frames in reporting Islam in selected Nigerian and Malaysian national daily newspapers.

\section{Reporting Islam in the Media}

Since the terrible events of $9 / 11$, the media's interest in Islam and Muslims has been significant, but deeply problematic in many ways. News reporting of Islam and Muslims is constantly ill-informed, and there is a general decline in journalistic standards in this regard. Islam and terrorism became inseparable in the messages disseminated via the media (Ahmad, 2006). In fact, terrorism has continued to be the main topic of coverage over time. Rather than providing any historical or political context, the acts of terrorism are clearly associated with Islamic belief. Therefore, the influence of stereotypes originating from the media, and the impact they have upon those who feel directly targeted should not be underestimated. Jaspal and Cinnirella's (2010) study focused specifically on media depictions of Muslims and hybridized threats to identity. The study brought additional understandings, presenting a socio-psychological approach to media depictions of Muslims. According to them, negative portrayal of Islam in the media has a double-function for identity. First, the negative portrayal tends to increase the uniqueness and self-esteem principles of identity among the readership. Second, the constant depiction of Muslims in terms of a symbolic, realistic, and hybridized threat to the ethno-national in-group may jeopardize the stability principle of identity, considering the high threats to the group's survival as a potent distinctive and collective social entity within intergroup contexts.

News stories focusing on Islam and Muslims are negatively framed in the media and limited to certain kinds of topics such as terrorism, radicalism, and domination of women. However, positive actions and critical topics like racism and discrimination against Muslims are relatively absent in the media coverage. The newspapers construct an inaccurate and negative image of Muslims and their religion, and thereby contribute to a general climate of bigotry and discrimination against Muslims. News coverage mostly portrays Muslim culture and Islam as posing a threat to democracy and freedom of speech, and priority is mostly given to topics that emphasized the immoral actions of Muslims in contrast to the good ones (Jacobsen, Jensen, Vitus, \& Weibel, 2012). In this regard, Rupar (2012) asserted that the poor instances of media coverage of Islam usually entail negative labeling, generalization of incidents, selective use of facts, reporting one side of a story, mixing facts and opinions, using pejorative words, lack of fact checking, and miss-matching of the content of headlines, text, images, and sound.

Kabir's (2010) study established that Islam or Muslims are only reported when a relationship with violence, militancy, extremism, or radicalism is involved. Another impression by the newspaper is that there is a focus on Islam or Islamic society only when there is a crisis situation. Since $9 / 11$, not only have anti-Muslim sentiments been reinforced, they have taken on a new twist. Events such as the invasion of Iraq, the situation in the Middle East, and the increasing use of suicide bombers have fuelled hostility toward Muslim communities globally. This has a significant effect on Muslims who are continuously portrayed as a threat by the press and government alike through misinformation, distortion of facts and negative stereotypes (Frost, 2008). Jacobsen et al. (2012) also posited that still negative stories dominate the media coverage of Islam and Muslims. Although Gardner et al. (2008) did not go into detail about the processes that are involved in deciding what particular images are presented, they provided a wealth of evidence to suggest that the media present negative view of Islam. These views might have an influence on people's perception about Islam (Ogan, Willnat, Pennington, \& Bashir, 2014).

It is also evident in Schneider's (2011) study that there is strong framing and construction of moral panic in newspaper articles, and the author considered his thorough assessment of Islamic discursive strategies in newspaper articles to be an advanced step of contribution to the previous literature in the area. Hostility in terms of moral panics means that Muslims are perceived as a threat to the values, interests and existence of the society. Framing is generally applied to create and support stereotypes. It significantly influences how readers perceive Muslims and Islam, since they are not likely to confirm and authenticate the information disseminated by the newspapers. In most cases, newspaper articles supporting hostility against Muslims explicitly emphasize on relationships between Islam and militancy, which has the tendency of creating fear of Islam and Muslims. Schneider (2011) found that the media present Muslims as offenders, thereby increasing suspicion toward them, which motivate people to reject Muslims as full members of the society because they are considered as a threat. This shows how the newspapers use framing to manipulate information against Islam and Muslims.

Muslims are facing negative societal representations, which is ascribed basically to the nature of media representations. They tend to be associated with negative phenomena such as terrorism, violence and immorality. 
The dominant representations of Muslims particularly in the western media have placed Muslims in a combination of hybridized and symbolic kind of threats to the dominant ethno-national in-group. Through negative reports on Islam in the media, society becomes less sympathetic to the concerns of Muslims. News about Muslims in newspapers is mostly distorted so that readers are likely to see a reflection of their own views and opinions. Newspapers eventually beguile the understandings of their readers and reciprocate the belief that 'Muslims are the problem'. As a result of negative media reports, Muslims are now perceived as a threat to western civilization. They are considered barbaric and hostile to the secular ways of the West. As Muslims become more noticeable as minority groups, and as the media ownership rests in the hands of few individuals, so that marginalized opinions are further dominated, how Muslims are depicted in the media will continue to remain increasingly negative (Abbas, 2001).

Many studies (Abbas, 2001; Jaspal \& Cinnirella, 2010; Kabir, 2010; Schneider, 2011) suggest that with the current improvements in communication technology, an unprecedented opportunity has been created to share and exchange information for knowledge and social change. But the media seem to turn the affairs into a war of words. This war of words is the cumulative actions of what has been framed and disseminated through the media (Haque, 2012). It is therefore evident that very few findings revealed positive coverage of Islam and Muslims in the media. The media's failure to accurately report the 'whole story' means that the complete picture is distorted. This does not help to promote the readers' knowledge and understanding; instead, it highlights the problem rather than providing solutions (Allen, 2014). Much communication literature proposes that news does not merely disseminate facts on a topic, but also serves as a source through which ideology is conveyed. Researchers pointed out that this can be identified in newspaper articles through the choice of words to depict a party involved in a particular event (Allen, 2001; Abbas, 2001; Moore, Mason, \& Lewis, 2008; Thussu, 2011; Schneider, 2011; Ridouani, 2011; Haque, 2012; Baker, Gabrielatos, \& McEnery, 2013; Allen 2014; Wariboko 2015), Islam in the case of this study.

\subsection{Theoretical Approach}

This study adopts Framing theory whose development is attributed to Goffman (1974). This theory regards meaning as residing primarily in the news messages. The journalists construct frame of news in the manner they select certain bits of information and ignore others, and how they construct stories to direct attention toward certain issues. The frame is the manner in which news story is presented; it is the news angle or the context for the story. The way in which news events are covered by the media can affect how receivers of that news come to understand the events. Recipients of a news story build their opinion based on how the story is framed (Potter, 2012; Freyenberger, 2013). As a media effects theory, Framing theory describes the influence of news angles used by journalists on the audience's perceptions. Angles refer to the interpretative and ideological frameworks from which journalists report about an issue and the conceptualization of news reports within a specific framework. A newspaper may decide to report about a person in a negative way, but the outcomes are that, the community being exposed to only the negative aspect in such report, will have negative perceptions about such person (Fourie, 2001). According to Creswell (2003), a general framework should be adopted to provide guidance about all facets of the study. Therefore, to guide and support arguments, the assumptions of Framing theory are considered in the present study.

\section{Method}

The researchers choose content analysis as it centers on media message characteristics. It also provides specific media content that can be analyzed to produce valid results and provide useful information. The advantages of using content analysis are numerous: It looks at communication via text and allows for both quantitative and qualitative analyses; it allows closeness to the text which can alternate between specific categories and analyzes the coded form of the text; it provides insight into complex model of human thought and language use; and it is considered a relatively research method based on facts, as opposed to Discourse Analysis (Weaver, 2007). According to Cohen (2007), "content analysis takes texts and analyses, reduces and interrogates them into summary form through the use of both pre-existing categories and emergent themes in order to generate or test a theory" (p. 476). Only articles related to Islam and Muslims were selected. The context and circumstance of coverage were studied from news frames in reporting Islam. The articles were analyzed based on headlines, texts, and pictures. Only Islam-related articles published in the selected newspapers between November 2015 and September 2016 were analyzed. The data were collected from relevant articles in the selected newspapers using purposive sampling technique and analyzed using content analysis.

Cross-tabulation was used to comparatively analyze the selected newspaper articles, taking into consideration the news frames. The study comparatively analyzed news articles in Nigerian and Malaysian newspapers. Both 
newspapers can be historically traced to the colonial era under the British colonial masters, and Muslims are the majority in both countries' population, having had earlier contact with Islam (Ridgeon, 2013; Saidu, 2014). Since most of the studies on media and Islam were conducted in Muslim-minority countries, it would be interesting to see how newspapers report Islam in the Muslim-majority countries. Gardner et al. (2008) noted that comparative analysis is proven to be the best way not only to help explain certain phenomena occurring in different countries, but also to clarify issues relating to one country by comparing them to similar issues in other countries. Dart and Allen (2000) also noted that one way to analyze charges of unfairness and preconceived notion in news reporting is to choose a particular issue and compare how various news organizations have handled the subject. Newspaper articles are the focus of this study as newspaper readers have a reasonable control level over their news consumption since they can attend to news at any time, as posited by Soroka (2002). Though data generated from newspaper content is qualitative in nature, but can be quantified to obtain valid results. It is clearly evinced in the work of Hsieh and Shannon (2005) that content analysis is classified as primarily a quantitative versus qualitative research method.

The study employed purposive sampling to select news articles included in the study. Purposive sampling refers to a form of non-probability sampling in which decisions concerning the elements to be included in the sample are taken by the researcher. It is superior to simple random sampling and consecutive day sampling because of its more adequate representation. It enables researchers to select a sample based on the purpose of the study (Langer, 1997; Neuendorf, 2002; Palys, 2008). Four national newspapers with highest readership were selected for analysis. Two newspapers form each country were chosen for comparison purpose. Punch and Vanguard were chosen from Nigeria while The Star and New Straits Times were chosen from Malaysia based on their online popularity and readership. These newspapers are the top daily English language publications (Abbott 2011; International Media \& Newspapers 2016; Thomas 2014; Answers Africa 2017). Regarding the newspaper articles, sample was collected from November 2015 until September 2016. This period represents the current scenario in the newspaper coverage of Islam, within which related events are happening around the globe. This time frame was chosen to make the data into manageable size for analysis. Considering the large number of articles, a sampling procedure was used to generate a reasonable number of articles for inclusion in the study. Rather than selecting a simple random sample of articles, a purposive sample was used. This procedure helps generate samples more suitable for the study.

The researchers conducted an internet-based search for newspaper articles on Islam. The aim was to locate the newspaper articles relating to Islam in the selected newspapers. The internet search was done using websites of the selected newspapers. The search method was to type the words 'Islam' and 'Muslims' as keywords. All newspaper articles identified using this method were included in the content analysis. Any article that focusses upon report about Islam or Muslims fulfills the inclusion criteria. The researchers selected articles that touched on issues directly related to Islam. Each article in the original sample was read for relevance. Only straight news and feature news stories were chosen for analysis.

The units of content analysis in this study are newspaper articles; straight news and feature stories form the selected newspapers. The data were coded to produce valid results. The present study adopted and modified the five news frames used in Semetko and Valkenburg (2000): 1) Conflict frame, which emphasizes conflict among and between individuals, groups or parties as a means of capturing audience's interest; 2) Consequence frame, which reports an event or issue in terms of the consequences on individuals, groups or parties; 3) Responsibility frame, which presents an event or issue in such a way as to attribute responsibility for its cause or solution to either an individual, group or party; 4) Morality frame, which puts an event or issue in the context of religious tenets or moral prescriptions; and 5) Human interest frame, which brings an emotional angle to the presentation of an event or issue. It refers to an effort to personalize and exaggerate the story in order to capture and retain audience's interest.

\subsection{Coding Procedure}

As pointed out by Neuendorf (2002), all decisions on variables, their measurement and coding rules must be made before the interpretations begin. Coding characteristics included the news frames mentioned in section 3.0, which consist of conflict frame, consequence frame, responsibility frame, morality frame, and human interest frame. At the preliminary stage of coding the data in the present study, all the selected articles were summarized, and a database was generated. Every single detail of the news articles, from expressions and choice of words to the descriptions and characters the story focuses on, was studied. This enables the researchers to identify the frame used in reporting Islam. Framing theory presumes that individuals construct reality through complex and reciprocal interactions among individuals, social groups, and products such as news articles (Eltantawy, 2007). The data were coded using hierarchical code system. The advantage of hierarchical coding is the amount of 
information it can represent in a relatively small number of digits (Hsieh \& Shannon, 2005). A second coder was hired to ensure reliability in this study. To assess the level of agreement between ratings on the article coding, Cohen's kappa test was used to measure inter-coder agreement for categorical items. Cross-tabulation was used to compare the variables. It is a joint frequency distribution of cases based on two or more categorical variables (Michael, 2001).

\section{Findings}

The newspapers produced different amounts of articles within the data collection period. Nigerian newspapers, Punch and Vanguard, produced 103 and 144 articles respectively. Meanwhile, Malaysian newspapers, The Star and New Straight Times, produced 193 and 159 articles respectively. The overall of 599 Islam-related articles were analyzed. The following tables depict detailed information on the articles produced by the selected newspapers.

Table 1 . Articles produced by the newspapers

\begin{tabular}{ccccc}
\hline & Newspapers & $\mathrm{N}$ & $\%$ & Total \\
\hline \multirow{2}{*}{ Nigerian Newspapers } & Punch & 103 & 41.7 & \\
& Vanguard & 144 & 58.2 & 247 \\
Malaysian Newspapers & The Star & 193 & 54.8 & \\
& New Strait Times & 159 & 45.1 & 352 \\
\hline
\end{tabular}

As shown in Table 1, Nigerian newspapers produced 247 articles while Malaysian newspapers produced up to 352 articles directly related to Islam. This clearly indicates that Malaysian newspapers produced more Islam-related articles within the chosen period of data collection. Though there might be several other articles that are indirectly related to Islam or Muslims, but due to the large number of these articles, only those directly related to Islam were selected. This account for the reason why the researchers relied on the purposive sampling techniques adopted in the study. The overall 599 newspaper articles $(\mathrm{N}=599)$ were analyzed. As explained earlier in section 3.0, only straight news and feature news were chosen for analysis. While Straight news is meant to report breaking news, and usually written or delivered in a short and straightforward form, feature article takes an in-depth look at a subject.

\subsection{The Use of News Frames in the Selected Newspapers}

As stated in section 3.1, five news frames used in Semetko and Valkenburg (2000) were adopted to examine how Islam is reported in the selected newspapers. These news frames are: conflict frame, which emphasizes conflict between individuals or groups; consequence frame, which consists of reporting events in terms of consequences on individuals or groups; responsibility frame, which refers to presenting an issue in such a way as to attribute responsibility for its cause or solution to individuals or groups; morality frame, which presents issues in the context of religious tenets or moral prescriptions; and human interest frame, which presents an emotional angle to presentation of an event or issue. The following table depicts the frames used by the selected Nigerian and Malaysian newspapers in reporting Islam.

Table 2. News frames used in the selected newspapers

\begin{tabular}{cccccc}
\hline \multirow{2}{*}{ News frames } & \multicolumn{2}{c}{ Nigerian newspapers } & \multicolumn{2}{c}{ Malaysian newspapers } & \multicolumn{2}{c}{ Total } \\
\cline { 2 - 6 } & $\mathrm{N}$ & $\%$ & $\mathrm{~N}$ & $\mathrm{~N}$ & $\mathrm{~N}$ \\
\hline Conflict & 121 & 48.9 & 107 & 30.3 & 228 \\
Consequence & 29 & 11.7 & 31 & 8.8 & 60 \\
Crime & 6 & 2.4 & 26 & 7.38 & 32 \\
Responsibility & 2 & 0.8 & 9 & 2.5 & 11 \\
Morality & 2 & 0.8 & 17 & 4.8 & 19 \\
Human interest & 87 & 35.2 & 352 & 100 & 249 \\
\hline Total & 247 & 100 & & 599 \\
\hline
\end{tabular}

Table 2 clearly indicates that almost half $(48.9 \%)$ of the articles published in the Nigerian newspapers portray Islam in the context of conflict while $30.3 \%$ of the articles published in Malaysian newspapers reported Islam in conflict situation. Also, Nigerian newspapers published more Islam-related articles using consequence frame 
(11.7\%) than Malaysian newspapers, which published $8.8 \%$. However, Malaysian newspapers published more Islam-related articles using crime frame $(7.38 \%)$ than Nigerian newspapers, which published only $2.4 \%$. Malaysian newspapers published more Islam-related articles using responsibility frame $(2.5 \%)$ than Nigerian newspapers, which published only $0.8 \%$. In addition, Malaysian newspapers attributed more Islam-related issues to morality $(4.8 \%)$ than Nigerian newspapers, which attributed only $0.8 \%$. It is also evident that the articles published in Malaysian newspapers are more of human interest frame (46.0\%) than those published in Nigerian newspapers $(35.2 \%)$.

Out of 599 Islam-related articles published in the selected newspapers, 228 portrayed Islam in conflict situation by using conflict frame. For the rest, 60 news articles used consequence frame, 32 used crime frame, 19 used morality frame, 11 used responsibility frame, and 249 portrayed Islam using human interest frame. Therefore, the overall articles published in the selected newspapers during the chosen period were more of human interest and conflict frames. Nigerian newspapers used more conflict frames in reporting Islam than Malaysian newspapers. This shows that while frames in Nigerian newspapers are more of conflict, those in Malaysian newspapers are more of human interest. The use of more conflict frames in Nigerian newspapers might not be unconnected with the issue of internal ethno-religious crisis that has been disturbing the tranquility of the state. But the overall articles are more of human interest frame, followed by conflict frame.

\section{Discussion}

The present study provides evidences on how the media, particularly newspapers, frame Islam. According to the findings, the overall articles published in the newspapers were more of human interest and conflict frames. This is contrary to Kabir's (2010) findings that the subject of Islam or Muslims was only reported in situations of violence. Similarly, Baker, et al. (2013) found that newspapers significantly make more reference to conflict in stories about Muslims. Wright (2007) also asserted that readers rarely have the opportunity to evaluate other kinds of information about religious groups that are not related to conflict; even stories which appear to be balanced also devote more attention to the conflict aspects. Though the newspapers in the present study used more human interest than conflict frames, they produced a substantial number of articles using conflict frame. Framing theory postulates that the manner in which news stories are reported by the media might influence the audience's understanding of the issues. By focusing on conflict in reporting Islam, the newspapers might portray negative image of the religion. Readers might develop their attitude based on the manner in which the news story is framed, in addition to their own individual frames. In this case, issues that may enhance the public's knowledge of typical Islamic teaching are mostly ignored by the media. Eltantawy's (2007) study also showed that the media give attention to certain bit of information and ignore others. This is in line with the conclusion of many studies (Yusof, Hassan, Hassan, \& Osman, 2013; Moore et al., 2008; Ahmad, 2006; Jacobsen, et al., 2012; Rane et al., 2014) on the relationship between media and Islam.

This study revealed that Malaysian newspapers tend to use more (46.0\%) human interest frame in reporting Islam than Nigerian newspapers (35.2\%). It might be argued that Malaysia experiences less conflict compared to Nigeria, which might be a reason for the newspapers to focus on human interest, responsibility, and morality frames instead of conflict. As presented in Section 4, this might account for why Malaysian newspapers produced more feature news stories than Nigerian newspapers. According to Institute for Economics and Peace report (2016), Malaysia was ranked $15^{\text {th }}$ in the global peace index while Nigeria was ranked $152^{\text {nd }}$. The report gave an in-depth analysis based on the current domestic and international conflict domain. In Nigeria, the symbiotic correlation between religion and politics has been the ground for conflicting ideological flows and the dominant factor that is shaping conflicts in the country. The most prevalent are those between the two major religions in the country - Islam and Christianity. Religion serves as the ideological inclination for national identity beyond any cultural or historical lines (Komolafe, 2012).

\section{Conclusion}

The findings reported in this study comparatively examined the use of frames in reporting Islam in selected Nigerian and Malaysian newspapers. It was evident that the most frequently used frames in the newspapers were human interest and conflict frames. Majority of the news articles used human interest frame in reporting Islam. Almost half of the overall Islam-related articles published in the selected newspapers portrayed Islam in the context of conflict. This study concludes that Nigerian and Malaysian newspapers use human interest and conflict frames in reporting Islam. In this regard, Hoover (2012) asserted that it is unfortunate that journalism uses conflict and the potential for conflict as a way of catching the attention of audience and selling newspapers. As a result, the media accentuate confusions and biases against the religion. By continuously presenting Islam and Muslims in a negative way, newspapers contribute to 'moral panic', but this does not mean the newspapers 
should not report about Islam. They are also not expected to offer special treatment to Muslims or overlook the problems, but issues should be clarified in context and cultural roots acknowledged. Newspapers should stick to journalism ethics and focus on public enlightenment on religious issues. This can be achieved through collective effort of journalists, editors, corporate ownership of the media, and by being conflict sensitive and restrictive to the actors.

\section{References}

Abbas, T. (2001). Media capital \& the representation of South Asian Muslims in the British Press: An ideological analysis. J of Muslim Minority Affairs, 21(2), 245-257. http://dx.doi.org/10.1080/1360200120092833

Abbott, J. P. (2011). Electoral authoritarianism and the print media in Malaysia: Measuring political bias and analyzing its cause. Asian Affairs: An American Review, 38(1), 1-38. http://dx.doi.org/10.1080/00927678. 2010.520575

Answers Africa. (2017). Top ten Nigerian newspapers. Retrieved from http://answersafrica.com/top-10-nigeriannewspapers-most-read-online.html

Ahmad, F. (2006). British Muslim perceptions and opinions on news coverage of September 11. Journal of Ethnic and Migration Studies, 32(6), 961-982. http://dx.doi.org/10.1080/13691830600761479

Allen, C. (2001). Islamophobia in the media since September 11th. Exploring Islamophobia: Deepening our understanding of Islam and Muslims. Conference of the Forum against Islamophobia \& Racism, London. Retrieved from https://mmu.rl.talis.com/items/B771DEA2-9EE8-BAD3-5B40-A9048D939A11.html

Allen, F. (2014). Islamophobia in the UK: The role of British newspapers in shaping attitudes towards Islam and Muslims (Doctoral dissertation). Available from Cadwrfa Ymchwil Research Repository.

Baker P., Gabrielatos C. \& McEnery T. (2013). Representations of Islam in the British Press 1998-2009. The ESRC Center for Corpus Approaches to Social Science, Lancaster University, UK. Retrieved from http://cass.lancs.ac.uk/wp-content/uploads/2013/12/CASS Islam-final.pdf

Cohen, L., Manion, L., \& Morrison, K. (2007). Research method in education. New York: Rutledge.

Creswell, J. W. (2003). Research design: Qualitative, quantitative, \& mixed methods approaches. London: Sage.

Dahinden, U., Koch, C., Wyss, V., \& Keel, G. (2011). Representation of Islam and Christianity in the Swiss media. Journal of Empirical Theology, 24(2), 197-208. https://doi.org/10.1163/157092511X603983

Eltantawy, N. M. A. (2007). US Newspaper Representation of Muslim and Arab Women Post 9/11 (Doctoral dissertation). Retrieved from http://scholarworks.gsu.edu/communication_diss/18/

Fourie, P. J. (2001). Media studies: Institutions, theories, and issues. Claremont: Jutaand Company Ltd.

Freyenberger, D. (2013). Amanda Knox: A Content Analysis of Media framing in newspapers around the world. (Master's thesis). Retrieved from http://dc.etsu.edu/cgi/viewcontent.cgi?article=2281\&context=etd

Gardner, R., Karakaşoğlus, Y., \& Luchtenberg, S. (2008). Islamophobia in the media: A response from multicultural education. Intercultural Edu., 19(2), 119-136. https://doi.org/10.1080/14675980801889658

Goffman, E. (1974). Frame Analysis: An essay on the organization of experience. New York: Haeper \& Row.

Haque, F. (2012). Global media, Islamophobia and its impact on conflict resolution. Retrieved from http://www.ihmsaw.org/resourcefiles/1260034024.pdf

Hoover, S. M. (2012). Religion and the media in the 21st century. Trípodos, 1(29), 27-35.

Hsieh, H. F., \& Shannon, S. E. (2005). Three approaches to qualitative content analysis. Qualitative Health Research, 15(9), 1277-1288. https://doi.org/10.1177/1049732305276687

Institute for Economics and Peace. (2016). Ten years of measuring peace. Retrieved from $\mathrm{http}: / /$ economicsandpeace.org/wp-content/uploads/2016/06/GPI-2016- Report_2.pdf

International Media and Newspapers. (2016). Top newspapers in Malaysia by 2016 Newspaper Web Ranking Retrieved from http://www.4imn.com/

Jacobsen, S. J., Jensen, T. G., Vitus, K., \& Weibel, K. (2012). Analysis of Danish media setting and framing of Muslims, Islam and racism. Retrieved from http://www.ces.uc.pt/projectos/tolerace/media/Working\%20 paper\%205/Analysis\%20of\%20Danish\%20Media\%20setting\%20and\%20framing\%20of\%20Muslims\%20I slam\%20and\%20racism.pdf

Jaspal, R., \& Cinnirella, M. (2010). Media representations of British Muslims and hybridised threats to identity. 
Contemporary Islam, 4(3), 289-310.

Kabir, S. (2010). Representation of French Muslim minorities in a New Zealand newspaper. The Jl of the South East Asia Res Centre for Comm \& Hum, 2(1), 33-46. http://dx.doi.org/10.1080/13602004.2012.727293

Komolafe, S. J. (2012). Politicization of reli-gion and the origins of funda-mentalisms in Nigeria (Part 1 of 3 ). Nigeriaworld News, 12, 1-7.

Langer, R. (1997). The concept of discourse in the analysis of complex communication events. Retrieved from http://openarchive.cbs.dk/bitstream/handle/10398/7028/wpnr.2\%201997.pdf?sequence=1

Michael, R. S. (2001). Crosstabulation \& Chi square. Indiana University, Bloomington. Retrieved from http://www.indiana.edu/ educy520/sec5982/we ek_12/chi_sqsummary011020.pdf

Moore, K., Mason, P., \& Lewis, J. M. W. (2008). Images of Islam in the UK: The representation of British Muslims in the national print news media 2000-2008. Retrieved from http://orca.cf.ac.uk/id/eprint/18277

Neuendorf, K. A. (2002). The content analysis guidebook. London: Sage Publications.

Ogan, C., Willnat, L., Pennington, R., \& Bashir, M. (2014). The rise of anti-Muslim prejudice: Media and Islamophobia in Europe and the United States. International Communication Gazette, 76(1), 27-46. https://doi.org/10.1177/1748048513504048

Palys, T. (2008). Purposive sampling. In L. M. Given (Ed.). The Sage encyclopedia of qualitative research Methods, 2, 697-698). Los Angeles: SAGE Publications.

Potter, J. W. (2012). Media effects. California: SAGE Publication Limited.

Rane, H., Ewart, J., \& Martinkus, J. (2014). Media-generated Muslims and Islamophobia. In Media Framing of the Muslim World (pp. 29-46). Basingstoke: Palgrave Macmillan.

Ridgeon, L. (2013). Islamic interpretations of Christianity. Milton Park: Routledge.

Ridouani, D. (2011). The representation of Arabs and Muslims in western media. Ruta: revista universitària de treballs acadèmics, 2(3), 45-57.

Rupar, V. (2012). Getting the facts right: Reporting ethnicity and religion. Brussels: European Commission

Saidu, S. (2014). A comparative analysis of production sharing contracts of selected developing countries: Nigeria, Indonesia, Malaysia and Equatorial Guinea. Journal of Finance and Accounting, 2(2), 34-40. https://doi.org/10.12691/jfa-2-2-2

Schneider, E. T. (2011). The Reproduction of Islamophobia in German and Dutch newspaper discourse: An analysis from a critical discourse analytical perspective (Bachelor's thesis, University of Twente).

Semetko, H. A., \& Valkenburg, P. M. (2000). Framing European politics: A content analysis of press and television news. J of Communication, 50(2), 93-109. https://doi.org/10.1111/j.1460-2466.2000.tb02843.X

Soroka, S. N. (2002). Agenda-setting dynamics in Canada. Vancouver, British Columbia: UBC Press.

Thomas, R. L. (Ed.) (2014). Monopolizing the nation: Soft censorship in Malaysia. World Association of Newspapers and News Publishers (WAN-IFRA). Retrieved from http://www.wan-ifra.org/articles/2014/ 12/18/monopolizing-the-nation-soft-censorshipmalaysia

Thussu, D. K. (2011). How media terrorism manipulates Truth. Economic and Political Weekly, 32(6), $264-267$.

Wariboko, O. P. (2015). Prospects of Islamophobia in Nigeria and its dangers. Journal of Religion and Human Relations, 7(1), 42-52.

Weaver, D. H. (2007). Thoughts on agenda setting, framing, and priming. Journal of Communication, 57(1), 142-147. https://doi.org/10.1111/j.1460-2466.2006.00333.x

Wright, S. A. (1997). Media coverage of unconventional religion: Any "good news" for minority faiths?. Review of Religious Research, 12(2), 101-115. https://doi.org/10.2307/3512176

Yusof, S. H., Hassan, F., Hassan, M. S., \& Osman, M. N. (2013). The framing of international media on Islam and terrorism. European Scientific Journal, 9(8), 104-121.

\section{Copyrights}

Copyright for this article is retained by the author(s), with first publication rights granted to the journal.

This is an open-access article distributed under the terms and conditions of the Creative Commons Attribution license (http://creativecommons.org/licenses/by/4.0/). 